\section{Barmah-Forest-Viren (BFV)}

W. Stöcker

Euroimmun Medizinische Labordiagnostika AG, Lübeck, Deutschland

\section{Englischer Begriff Barmah forest virus}

Beschreibung des Erregers Familie: Togaviridiae; Gattung: Alphavirus; Art: Barmah forest virus. PlusstrangRNA-Genom, behüllt, 60-70 nm Durchmesser; enge Verwandtschaft zu Ross-River-Viren.

Erkrankungen Vorkommen: Australien.

Vektoren: Stechmücken (Culex ssp., Aedes ssp.).

Wirte: Menschen; natürliches Virusreservoir bislang nicht eindeutig identifiziert, eventuell Vögel.

Klinik: endemische Polyarthritis; saisonales Auftreten der Erkrankung vor allem im Sommer und Herbst bzw. Frühling in Westaustralien; nach einer Inkubationszeit von 5-21 Tagen können Fieber, Arthralgie mit Arthritis, Hautausschlag und Lethargie auftreten; bei etwa $10 \%$ der Fälle persistieren Arthralgie und Myalgie über mehrere Monate.

Analytik Direktnachweis: Virusisolation oder Nachweis viraler RNA durch RT-PCR (Polymerase-Kettenreaktion).

Serologie: Nachweis spezifischer Antikörper (IgM, IgG) im Serum durch indirekte Immunfluoreszenz $(\triangleright$ Immunfluoreszenz, indirekte), $\triangleright$ Enzyme-linked Immunosorbent Assay oder $\triangleright$ Neutralisationstest.
Probenmaterial Direktnachweis: Blut und Blutbestandteile, Gewebe. Das Material sollte bis zur Weiterverarbeitung bei +4 bis $+8{ }^{\circ} \mathrm{C}$ aufbewahrt werden.

Serologie: Serum oder Plasma für den Nachweis der Antikörper sind bei $+4{ }^{\circ} \mathrm{C}$ bis zu 2 Wochen lang beständig, bei $-20{ }^{\circ} \mathrm{C}$ über Monate und Jahre hinweg. Zur Tiefkühlkonservierung des IgM kann man den Proben 80 \% gepuffertes Glyzerin beifügen.

Diagnostische Wertigkeit Die Anamnese, insbesondere Informationen über längere Aufenthalte in Endemiegebieten ist wichtig. Der direkte Virusnachweis ist grundsätzlich möglich, gelingt aber selten. Serologische Tests zum Nachweis von Antikörpern sind vorzuziehen. Zu Beginn der Symptomatik sind spezifische IgM-Antikörper bei der Mehrzahl der Patienten vorhanden. Ein gegenüber der ersten Probe gemessener signifikanter Anstieg des Anti-BFV-IgG-Titers in einer zweiten Serumprobe (Abstand zwischen den Blutentnahmen ca. 2 Wochen) gilt als sicherer Beleg für die Infektion. Kreuzreaktivitäten mit Antikörpern gegen koendemische Alphaviren sind möglich.

\section{Literatur}

Cashman P, Hueston L, Durrheim D, Massey P, Doggett S, Russell RC (2008) Barmah Forest virus serology; implications for diagnosis and public health action. Commun Dis Intell 32(2):263-266

Dobler G, Aspöck H (2010) Durch Stechmücken übertragene Arboviren als Erreger von Infektionen des Menschen. In: Aspöck H (Hrsg) Krank durch Arthroponden. Denisia 30, Linz: Land Oberösterreich, Biologiezentrum/Oberösterreichische Landesmuseen, S 501-553 